\author{
N.N. Khanina ${ }^{1}$, I.V. Li $^{2}$ \\ ${ }^{I}$ Zhetysu University of the name of I. Zhansugurov, Taldykorgan, Kazakhstan \\ ${ }_{2}^{2}$ Abai Kazakh National Pedagogical University, Almaty, Kazakhstan \\ (Corresponding author's E-mail: khanina-nadezhda@mail.ru)
}

\title{
Senior preschool children's speech development through dialogue with peers
}

\begin{abstract}
The article is devoted to the relevant problem of speech development, specifically its dialogic component. The development of coherent dialogic speech as a means of forming communication skills plays an important role in the process of preschoolers' speech development. As a form of speech interaction with other people, dialogue requires special social and speech skills from the child, the development of which occurs gradually. Dialogue for a child is the first school of mastering speech, the school of communication; it is, in fact, the base of personal development. Through dialogue children learn the grammar of their native language, its vocabulary, phonetics, and draw useful information. The topic is relevant, since the development of dialogue in preschool childhood affects the formation of speech and communicative abilities, which are one of the aspects of individual success in modern society. The article focuses on the cooperative type of activities that are particularly important for the development of dialogic speech, primarily in which children jointly create a subject-game environment, come up with a theme and develop a plot, role-play dialogues and in the course of them enter into a variety of real relationships. The program that includes a set of didactic games for older preschoolers and is aimed at improving the level of dialogic communication skills is proposed. An experiment was conducted and described in which a set of didactic games was tested. The experiment showed growth in the skills of dialogic speech.
\end{abstract}

Keywords: dialogue, speech, communication, communication skills, didactic games, speech development, senior preschool age, dialogic communication.

\section{Introduction}

Speech is the most important creative mental function of a person, the area of manifestation of the inherent ability of all people to learn, self-organize, self-develop, build their personality and inner world through dialogue with other people. A person improves his speech all his life, mastering the language skills. Each age stage brings something new to speech development. The most important stages in the mastery of speech accounts for childhood are its preschool and school periods.

Dialogue with a peer is a field of cooperation pedagogy, pedagogy of self-development. Direct instructions, educational motivation, and strict regulations are inappropriate here. And yet, as studies show (L.S. Vygotsky [1], L.P. Yakubinsky [2], D.B. Elkonin [3], M.M. Bakhtin [4]), dialogue with a peer should be taught, as well as language games verbal creativity.

Even Vygotsky [1] noted the fact that it is on the basis of dialogue (the primary form of speech) a monologue is formed - the highest form of speech that developed historically later than dialogue. It is obvious that dialogue is born because of a person's need for communication.

The characterization of dialogic speech is given in a number of works: L.P. Yakubinsky "O dialogicheskoi rechi (On dialogic speech)" [2]; T.G. Vinokur "O nekotorykh sintaksicheskih osobennostyah dialogicheskoi rechi (On some syntactic features of dialogic speech)" [5]. Thus, T.G. Vinokur defines dialogue from the point of view of the language specifics: "...a dialogue can be defined as a special, functional and stylistic form of speech communication, which is characterized by the presence of two or more participants exchanging speech; a more or less rapid pace of speech, when each component of it is a reply; comparative brevity of repliess; conciseness and ellipticity of constructions within replicas". The authors conducted experimental studies in preschool institutions and found that children have difficulty in communication with peers. The authors developed scenarios and implemented them in the practice of developing dialogic communication in preschool institutions. As the main form of training, they used gamesclasses.

In the work on the theory and methodology of preschool childrens' speech development by A. Arushanova [6] it is said that the formation of dialogic speech is realized in the process of conversations between the teacher and children in everyday communication and in the form of specially prepared conversations. The method of conducting a conversation with children is described in the works of E.I. Tikheeva [7] 
and E.A. Flerina [8]. The classification of conversations, their target setting and the method of conducting them were developed by E.A. Fleerina.

Based on the data of the above studies, there is a need for a complex approach to the formation of dialogic speech and the unacceptability of reducing the tasks of teaching dialogue only to the question-answer form development. In the practice of preschool institutions we observe the opposite trends. Nowadays, the problem of speech communication in the context of organized learning has not been sufficiently studied, there is no classification of games for the development of dialogue, joint games.

This topic is relevant in this regard, since the development of dialogue in preschool childhood affects the formation of speech and communicative abilities. Specifically, the communicative abilities are one of the aspects of the successful presence of the individual in contemporary society.

The aim of our research is to study the features of the of the development dialogic form of speech by senior preschool age children and to develop a pedagogical program for the creation of the dialogic form of speech.

Objectives of the study:

1. To identify the level of dialogic speech formation of 5-6 years old children on the basis of psychological and pedagogical research on the problem.

2. To develop a pedagogical program, that includes the content and methodology of language games and exercises aimed at developing the dialogue of older preschool children.

Based on the research carried out under the leadership of F.A. Sokhin [9] and O.S. Ushakova [10] and such scientists as L.G. Shadrina, A.A. Smaga, A.I. Lavrentiev, G.I. Nikolaichuk, L.A. Kolunov, we determined that cooperative activities are especially important for the development of dialogic speech, primarily creative story-role-playing games, in which children jointly create a subject-playing environment, invent a theme and develop a plot, play role-playing dialogues and, in the course of them, enter into a variety of real relationships.

Games and exercises for the development of preschool children dialogic speech were developed by O.S. Ushakova and E.M. Strunina [11]. We consider the development of creative games as an indicator of children's communicative competence.

\section{Materials and Methods}

Our main research methods were:

- study and analysis of psychological, pedagogical and special literature on the topic of research;

- analysis of the content of various didactic materials;

- monitoring the activities of children in the classroom and in everyday life;

- the pedagogical experiment designed to foster speech development through the dialogue of preschool children.

In order to identify the level of 5-6 year old children dialogic speech formation an ascertaining experiment was conducted. We used a modified test by M. Lisina, which allows us to identify first of all the level of formation of the motivational sphere, that is, to determine what the main activity of children is aimed at: playing, reading or talking. This allows to find out the main object of the child's attention, which helps to identify the level of their speech activity.

The basis of these methods is a set of tasks and exercises, as well as games and conversations aimed at identifying:

- the child's desire to communicate and make contact;

- ability to make contact;

- ability to navigate the social situation;

- self-sufficiency, and so on.

For the control experiment two groups were allocated: experimental - senior group " $\mathrm{A}$ " of kindergarten \#42. The group consisted of 25 children, which possessed the normal psychological climate. And the control group - senior group "B" with 25 children. The training was conducted in 2019-2020. In the control group the training was based on the traditional method of speech development in kindergarten. In the experimental group the training was based on the methodology developed in our study, which includes special tasks, exercises and games for the development of communication skills. At the first stage the method was used, where the child is offered 3 types of activities: play, conversation or reading a book. 
Teacher: "Please tell me, would you like to play, read a book together, or talk?" Depending on the choice, children are asked questions. If children cannot make a choice on their own, the adult suggests playing first, then reading, then conversation. The examination is carried out individually in a separate room, each situation approximately lasts for 15 minutes.

After analyzing the data of the first stage we came to the conclusion that in experimental group "A":

$-12 \%$ of children have a high level of development of communication abilities;

$-56 \%$ showed average results;

$-32 \%$ revealed a low level of development of communication abilities.

The control group of children showed the following results:

$-17 \%$ of the surveyed group showed a high level of development of communication skills;

$-54 \%$ showed average results;

$-29 \%$ revealed a low level of development of communication skills.

Summing up the results of our study, we see that in the experimental group 14 out of 25 children have difficulties communicating, and 8 of them will not be able to cope with these difficulties alone, they need qualified help and support. These children have a low level of coherent speech development, they have obstacles in coming into contact with peers, moreover, they have difficulty contacting an adult with a request, and so on. All this indicates an alarming state of speech development in them. The reason for this are often adults, who often do not notice how difficult it is for a child to establish contact with anyone other than family or the immediate environment. The development of communication skills in preschool childhood has a huge impact on the development of dialogue at school age, and therefore on the formation of speech in general.

When organizing the formative experiment, we relied on the position that the classes, during which the method of indirect influence was used, are the most effective. The main task of the formative experiment is to develop the ability of older preschool children to independently choose a way to achieve communication with their peers and adults.

We taught dialogic communication in the form of lessons of activating communication in kindergarten \#42 (Taldykorgan city). The communication scenario includes a dialogue between the teacher and children, didactic, mobile, pair games, dramatizations, games-dramatizations, in classes' visual activities. Activities are developed so speech acts in all its various functions, bears the main burden in solving practical and cognitive tasks.

In the proposed scenarios of activating communication a number of tasks are identified that are already traditional for the speech development methodology: enriching and activating the vocabulary, educating the sound culture of speech, forming the grammatical structure of the child's language, and developing coherent speech. To solve them special complex speech classes have been developed, for example, in the works of M.M. Alekseeva, V.I. Yashina [12] and others. During our classes specific language material, game tasks and problem situations were selected in such a way as to activate speech communication between children, their initiative statements, questions, stories from personal experience, involuntary situational speech, the use of non-verbal means of communication, as well as to initiate amateur linguistic experiments and language games. At the same time, we proceeded from the L.S. Vygotsky's [1] point of view about the self-worth of the age stage of preschool childhood. Such a valuable type of activity is the initiative involuntary speech of children, their emotional personal contact, achieved with the help of verbal and non-verbal means (facial expressions, gestures, postures, gaze, objective actions), those are components of communication that develop a dialogue. Thus, those special speech classes that solve the problems of language development are transformed so as to simultaneously solve the obstacle of establishing emotional personal contacts between children. This is achieved by changing the style of the relationship between the teacher and the children, by changing teaching position to a partner one.

The teacher's duty is to form a communicative culture, which includes establishing friendly relations among children, developing their interest in everything that happens, creating an atmosphere of goodwill, mutual respect and trust, compliance and, at the same time, initiative. To achieve this, in our opinion, the organization of work in small groups is most suitable. Working in small groups is less tiring for children, as they are in closer contact with each other. Children in small groups work on the principle of "if you know it, tell another" and "if you know how to do it, teach another". It is also important that small groups form a selfassessment. The child learns to objectively compare their own skill with the skills of peers, to compare their opinion with the opinions of others. That is why at the beginning we offer children paired tasks, that is, tasks that require the participation of two children. In this way we help children to find common language with a 
peer in the form of a game, to go with him to "contact", to be precise. After the children have mastered these techniques, they are offered a complication: games in which it is necessary to divide into small subgroups of 4-6 people.

The dialogue development program consisted of a set of classes, games, and sessions of activating communication.

The organization of the story-role-playing game as a sphere of children's communicative self-activity had a great effect, which assumed their freedom in choosing partners, topics and game actions and allowed a pedagogue to participate only in the role of an equal partner. Dialogic communication developed in a creative game as a result of self-development. The emergence and resolution of contradictions between the means of communication available to children and the requirements for their effectiveness in the game the mechanism of such self-development. The children were passionate about the game, they themselves mastered new means and ways of communication, which they lacked and need. Therefore we observed the development of dialogic communication in the story-role-playing game, which had a developing influence through the creation of a subject-game environment, enriched the children's knowledge about the environment and social relations.

Of particular importance for the development of dialogical communication with peers were verbal didactic games with small subgroups of children (2-3 people). The rules of the game encouraged children to listen and hear the partner, to ask questions if necessary, give instructions, express agreement or disagreement with the partner's game and speech actions, argue the statement, reason, follow the order, respond to the statements of the interlocutor.

During the game "Little Tiger's Birthday", the goal was: to consolidate the ability to coordinate nouns with adjectives in gender and number as well as speech etiquette skills development. Speech etiquette includes address, introduction, greeting, apology, sympathy, congratulations, gratitude, farewell, and so on. It's also important to form the capability to communicate in a pair, a group of 3-5 people, in a team.

The plot of the game. On the birthday of the Little Tiger Roma, guests came. They congratulate the Tiger, get acquainted with each other, greet guests, make a request. The gifts they brought are not simple, but with a surprise, a mystery. And to get them to the Tiger Roma, a help is needed to solve the riddles. The main rule of the game is that objects and toys appear when the correct answer is found, and children use the rules of speech etiquette. Then the guests made riddles.

The game situation is aimed at mastering the rules, confirming that the child consciously calls the word, focuses on the grammatical form. At the beginning of the game the children found it difficult to explain their answer, politely address the guests, start a conversation, so the teacher came to help, explaining without using grammatical terms, that we would say, for instance, about the locomotive: "Beautiful, big, clockwork", and about the dandelion - "fragrant, aromatic, yellow". Further, the children proved the correctness of their answer. At the same time, this contributed to the formation of elements of explanatory speech, children practiced the use of complex sentences and formed communication skills.

The game "Let's Brag" was planned with the aim of teaching children the comparative degree of adjectives, and for the development of the following communication skills: to consolidate the ability to participate in a general conversation, listen carefully to the interlocutor, not to interrupt them, not to be distracted. Special attention was paid to the ability to formulate and ask questions, build an answer in accordance with what they heard, supplement, correct the interlocutor if necessary, compare their point of view with others opinions.

The plot of the game. The children read the folk tale "The Hare-Braggart". The teacher asked: "Was it really about the giant hare?" "No, the braggart. Today we have two little hares who like to show off. Only one of them succeeded at it, and the other constantly forgets the word, help him". A dramatization is being played out. During the dramatization children play roles while removing the communicative barriers between each other.

One child-hare says: "I have long ears" and the other: "And I have even... (longer)" the children suggest. "My legs are fast — and I have... (faster) legs", "the fur coat is soft — and I have...(softer)". The teacher spoke for the first hare, called the initial form of the word, the second was helped by the children.

During the game "On the roof of Karlsson", the following tasks were solved: the formation of the genitive case of plural nouns, the ability to answer and ask questions, and to conduct a conversation. The speech material that causes difficulties in children was offered. The main game rule that performs the control action is that items do not appear if they are named incorrectly. The attention of children is drawn to the grammatical correctness of speech, the desire to speak correctly was developed. 
Description of the game. On the teacher's desk is Karlsson's room and the fairy-tale character himself. Karlsson turns to the children: "Thank you, friends, for coming to help, my things have disappeared somewhere". The children answer and the object appears; Karlsson is happy and asks to answer his questions. Then the words were suggested: "matches", "chairs", "shoes", "pictures", "candles", "glasses", "spoons", "stockings", "socks". Over the course of the game the children cleaned up Karlsson's room, had a conversation with him, and put things in their places.

One of the methods of developing dialogic speech is conversation. A conversation is an organized discussion between a teacher and the entire group of children, dedicated to one particular issue.

In the conversation the preschool teacher:

1) clarified and organized the children's experience, that is, the ideas and knowledge about people life and nature that children acquired during observations under the guidance of a teacher and in various activities in the family and in kindergarten;

2) trained the children's correct attitude to the environment;

3) taught children to think purposefully and consistently, without getting disracted from the topic of conversation;

4) taught to express thoughts simply and clearly.

In addition, during the conversation the teacher brought up children's steady attention, the ability to listen and understand the speech of others, to restrain the desire to immediately answer a question without waiting for a call, the habit of speaking loudly and clearly enough for everyone to hear.

Methodically, the ratio of adult and child speech in a conversation is important. As observations show, often the speech activity of the teacher prevails over the child's. Sometimes teachers asking a question do not give children the opportunity to concentrate and think, they hurry to answer themselves, starting to talk about what they observed, for example, on an excursion. Children have no choice but to listen passively. The other extreme is to "pull" the correct answers from children at the cost of considerable effort. The effectiveness of the conversation largely depends on the teacher's ability to purposefully lead children, direct children's thoughts and activate speech activity.

Didactic games with a doll, which consisted in playing a small dramatization with the participation of a doll, were effective as method of speech development. Children talk to each other by themselves on behalf of the dolls. This form of conversation corresponds to children's interests and serves as an excellent means of activating children's speech. They follow each other's actions with interest, listen carefully, answer readily, and ask questions themselves. Conducting such classes required prior preparation from the teacher. A script was drawn up where the actors, the order of actions and the approximate speech of the actors are listed.

Pair interaction was also effectively organized in the process of collective speech training. For this purpose tasks with split pictures were used to compose a story based on a series of pictures or on conditional schemes, games with collective drawing of the type "Remember and draw", as well as a game in a circle with a ball "End the sentence".

The program defines in which age groups classes-conversations are held. In relation to the younger preschool age a conversation in the process of gaining experience is used. The conversation is accompanied by viewing toys, pictures.

In the middle preschool age conversations accompanying the acquisition of new knowledge and observations are mainly used, (what objects are made of, our clothes, washing accessories) and excursions (what the postman does). In the older preschool age, all kinds of conversations are held.

According to the same principle, games in which the material was a variety of toys, dishes, furniture, story pictures were built. The teacher chose language tools that were quite accessible to the preschoolers in order to increase the emotionality and imagery of their speech, thereby deepening the perception of the picture and introducing children to the richness of language riches.

\section{Results and Discussion}

At the end of the development work a final evaluation was carried out, which allowed us to see how much the level of communicative development through dialogue of older preschool children has changed.

In the control group, there is a smooth growth dynamic:

- high level - $32 \%$ (8 preschoolers);

- average level $-52 \%$ (13 children);

- low level - $16 \%$ (4 children). 
Comparative results are shown in Figure 1.

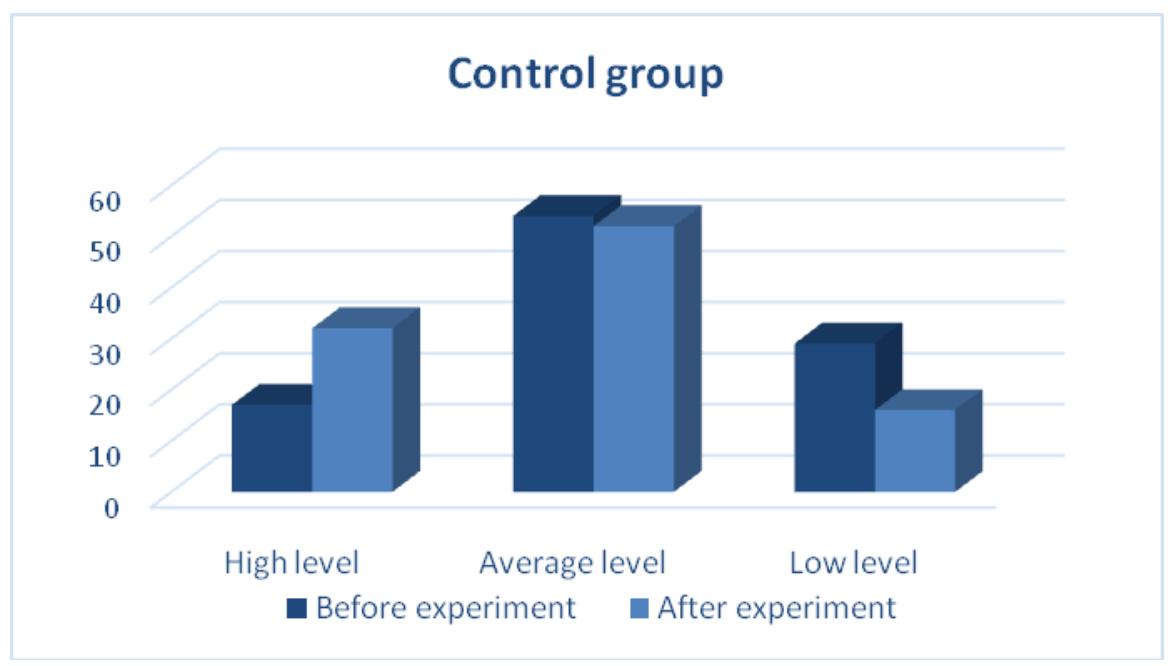

Figure 1. Comparative results of control group

In the experimental group it is necessary to note a significant increase in the number of children who showed a high level of communicative development (it increased from 3 to 10 children - $40 \%$ ). The average level was shown by 12 children, which was $48 \%$. The number of children showing a low level of communicative development also decreased (from 8 to $3-12 \%$ ).

Comparative results are shown in Figure 2.

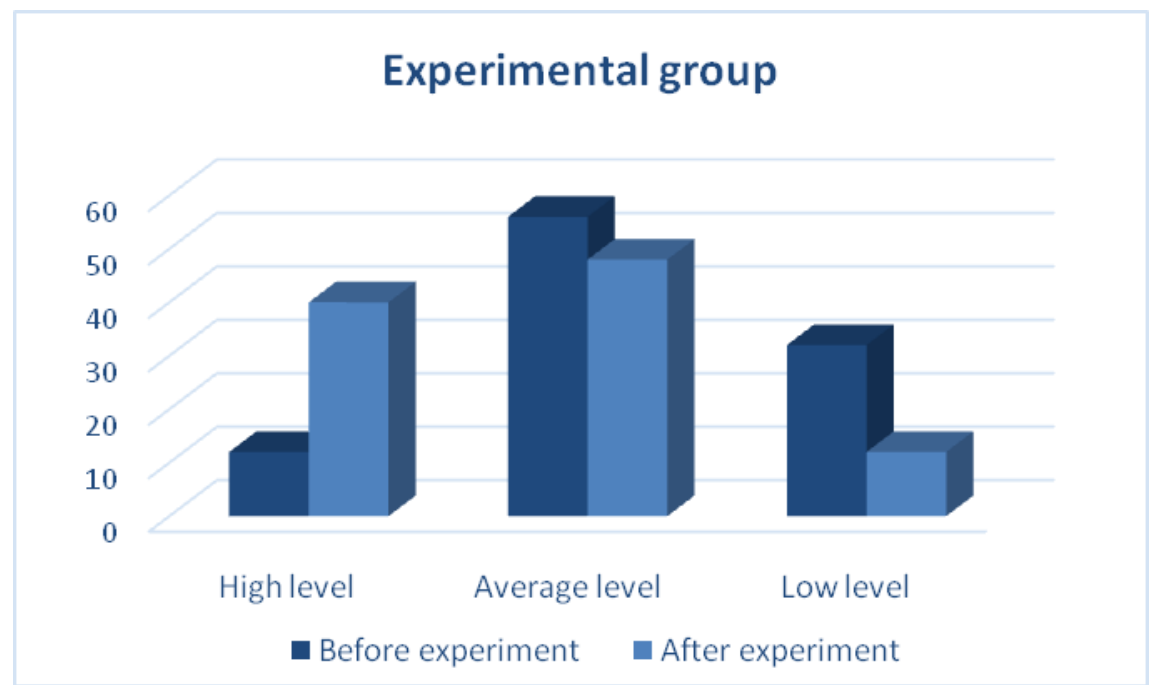

Figure 2. Comparative results of experimental group

After analyzing the data from these tables we came to the conclusion that children who are engaged in the usual program cannot independently overcome the difficulties and obstacles that arise in the way of holding a good conversation and speech development in general. Our programs aim is to help these children. The results of the control experiment confirm positive results.

\section{Conclusions}

Based on results of the study we conclude that dialogue will serve the purpose of developing children's speech under the following conditions:

- identification of the causes of the insufficient level of speech development;

- taking into account the age, psychophysiological features of the formation of speech activity of preschool children; 
- psychological and pedagogical readiness of the teacher to organize a dialogue and further teach preschoolers to conduct a dialogue;

- taking the role of peers in the speech development of children into account.

The accomplishment of speech exercises organically included in the structure of educational dialogue organization in the classroom in preschool. The purposeful organization of the educational dialogue should include the support of the educator for the communication needs of children and the development of motivation for productive cooperation based on the subjective speech experience of children. The assimilation of the simplest theoretical knowledge of speech is carried out by setting and solving educational tasks under the guidance of a teacher, and then independently, forming the skills and abilities of conducting a culture of dispute, teaching preschoolers to self-reflect.

Taking into account these aspects, we came to the conclusion that it is the experience of dialogical communication with peers and adults in preschool age that later has a huge impact on the formation of the personality in general.

\title{
References
}

1 Выготский Л.С. Мышление и речь/ Л.С. Выготский. - Т. 2. - Гл. 1. М.: Педагогика, 1982. - С. 10-23.

2 Якубинский Л.П. О диалогической речи / Л.П. Якубинский // Язык и его функционирование: избр. работы. - М., 1987. - С.17-59.

3 Эльконин Д.Б. Развитие речи в дошкольном возрасте / Д.Б. Эльконин. - М.: Изд-во АПН РСФСР. 1968. - 115 с.

4 Бахтин М.М. Проблема речевых жанров. Эстетика словесного творчества / М.М. Бахтин. - М., 1986. - С. $250-269$.

5 Винокур Т.Г. О некоторых синтаксических особенностях диалогической речи. Исследования по грамматике русского литературного языка / Т.Г. Винокур. - М.: Изд. АН СССР, 1955. - 154 с.

6 Арушанова А. Организация диалогического общения дошкольников со сверстниками / А. Арушанова // Дошкольное воспитание. - 2001. - № 5. - С. 51-61.

7 Тихеева Е.И. Развитие речи детей / Е.И. Тихеева. - М.: Просвещение, 1972. — 280 с.

8 Флерина Е.А. Разговорная речь в детском саду // Хрестоматия по теории и методике развития речи детей дошкольного возраста / Сост. М.М. Алексеева / Е.А. Флерина. - М.: Академия, 1999. — 210 с.

9 Сохин Ф.А. Развитие речи детей дошкольного возраста: пос. для воспитателя детского сада / Ф.А. Сохин. - М.: Просвещение, 1979. - 223 с.

10 Ушакова О.С. Развитие речи дошкольников: игры, упражнения, конспекты занятий / О.С. Ушакова. — 3-изд., испр. — М.: ТЦ «Сфера», 2014. - $176 \mathrm{c}$.

11 Струнина Е.М. Семантический аспект в развитии речи старших дошкольников / Е.М. Струнина, О.С. Ушакова; под ред. О.С. Ушаковой // Развитие речи и речевого общения дошкольников. - М., 1995. - 21 с.

12 Алексеева М.М. Теория и методика развития речи детей: учеб. для студ. учрежд. высш. проф. обр. / М.М. Алексеева, В.И. Яшина. - М.: Академия, 2013. - 448 с.

\author{
Н.Н. Ханина, И.В. Ли
}

\section{Кұрдастарымен диалог арқылы ересек мектеп жасына дейінгі балалардың сөйлеуін дамыту}

\begin{abstract}
Мақала бүгінгі таңда сөйлеуді дамытудың өзекті мәселесіне, атап айтқанда оның диалогтық компонентіне арналған. Қарым-қатынас дағдыларын қалыптастыру құралы ретінде үйлесімді диалогтік сөйлеуді дамыту оқушылардың сөйлеу қабілетін дамыту процесінде маңызды рөл атқарады. Басқа адамдармен сөйлесудің өзара әрекеттесу формасы ретінде диалог баладан біртіндеп дамып келе жатқан ерекше әлеуметтік-сөйлеу дағдыларын қажет етеді. Бала үшін диалог - бұл сөйлеуді игерудің алғашқы мектебі, қарым-қатынас мектебі, ол негізінен дамып келе жатқан жеке тұлға. Диалог арқылы балалар ана тілінің грамматикасын, оның сөздігін, фонетикасын үйренеді, пайдалы ақпарат алады. Тақырып өзекті, өйткені мектепке дейінгі балалық шақта диалогты дамыту сөйлеудің қалыптасуына, коммуникативті қабілеттердің қалыптасуына әсер етеді. Атап айтқанда, коммуникативтік қабілеттер қазіргі қоғамда адамның табысты өмір сүруінің аспектілерінің бірі болып табылады. Мақалада кооперативті типтегі диалогтық сөйлеуді дамыту үшін ерекше маңызды іс-шараларға, ең алдымен шығармашылық сюжеттік-рөлдік ойынға баса назар аударылған, онда балалар бірлесіп тақырыптықойын ортасын жасайды, тақырыпты ойлап табады және сюжетті дамытады, рөлдік диалогтар ойнайды және олар әртүрлі нақты қатынастарға енеді. Диалогтық қарым-қатынас қабілеттерін арттыруға бағытталған үлкен мектеп жасына дейінгі балаларға арналған дидактикалық ойындар бағдарламасы
\end{abstract}


ұсынылған. Эксперимент жүргізілді және сипатталды, онда дидактикалық ойындар кешені сыналды. Экспериментте диалогтік сөйлеу дағдыларының артқаны көрсетілген.

Кілт сөздер: диалог, сөйлеу, коммуникация, қарым-қатынас дағдылары, дидактикалық ойын, сөйлеуді дамыту, мектепке дейінгі жастағы бала, диалогтік қарым-қатынас.

\section{Н.Н. Ханина, И.В. Ли}

\section{Развитие речи старших дошкольников через диалог со сверстниками}

Статья посвящена актуальной на сегодняшний день проблеме развития речи, а именно ее диалогической составляющей. Развитие связной диалогической речи как средство формирования коммуникативных навыков играет важную роль в процессе речевого развития обучающихся. Как форма речевого взаимодействия с другими людьми, диалог требует от ребенка особых социально-речевых умений, освоение которых происходит постепенно. Диалог для ребенка является первой школой овладения речью, школой общения, он, по существу, является основой развивающейся личности. Через диалог дети усваивают грамматику родного языка, его словарь, фонетику, черпают полезную информацию. Тема является актуальной, так как развитие диалога в дошкольном возрасте влияет на становление речи, формирование коммуникативных способностей, которые являются в современном обществе одним из аспектов успешного существования личности. В статье акцентировано внимание на особенно важных для развития диалогической речи видов деятельности кооперативного типа, прежде всего, в которой дети совместно создают предметно-игровую среду, придумывают тему и развивают сюжет, разыгрывают ролевые диалоги и по ходу их вступают в разнообразные реальные взаимоотношения. Предложена программа, которая включает комплекс дидактических игр для старших дошкольников и направлена на повышение уровня диалогических коммуникативных способностей. Был проведен и описан эксперимент, в котором был апробирован комплекс дидактических игр. Эксперимент показал повышение навыков диалогической речи.

Ключевые слова: диалог, речь, коммуникация, коммуникативные навыки, дидактическая игра, развитие речи, старший дошкольный возраст, диалогическое общение.

\section{References}

1 Vygotsky, L.S. (1982). Myshlenie i rech [Thought and language]. Moscow: Pedagogika [in Russian].

2 Yakubinsky, L.P. (1987). O dialogicheskoi rechi [On dialogic speech]. Yazyk i eho funktsionirovanie: Izbrannye raboty [Language and its functioning: Selected works]. Moscow [in Russian].

3 Elkonin, D.B. (1968). Razvitie rechiv doshkolnom vozraste [Speech development in preschool age]. Moscow: Publ. APN RSFSR [in Russian].

4 Bakhtin, M. M. (1986). Problema rechevykh zhanrov. Estetika slovesnogo tvorchestva [The problem of speech genres. Aesthetics of verbal creativity]. Moscow [in Russian].

5 Vinokur, T.G. (1955). O nekotorykh sintaksicheskikh osobennostiakh dialogicheskoi rechi [On some syntactic features of dialogic speech]. Issledovaniia po grammatike russkogo literaturnogo yazyka [Research on the grammar of the Russian literary language]. Moscow: Publ. AN SSSR [in Russian].

6 Arushanova, A. (2001). Organizatsiia dialogicheskogo obshcheniia doshkolnikov so sverstnikami [Organization of dialogical communication of preschool children with their peers]. Doshkolnoe vospitanie - Preschool education, 5, 51-61 [in Russian].

7 Tikheeva, E.I. (1972). Razvitie rechi detei [Children's speech development]. Moscow: Prosveshchenie [in Russian].

8 Flerina, E. A. (1999). Razgovornaia rech $v$ detskom sadu [Colloquial speech in kindergarten]. Khrestomatiia po teorii $i$ metodike razvitiia rechi detei doshkolnogo vozrasta [Textbook on the theory and methodology of speech development in preschool children]. M.M. Alekseeva (Ed.). Moscow: Akademiia [in Russian].

9 Sokhin, F.A. (1979). Razvitie rechi detei doshkolnogo vozrasta: posobie dlia vospitatelia detskogo sada [Speech development of preschool children: manual for a preschool teacher]. F.A. Sokhin (Ed.). Moscow: Prosveshchenie [in Russian].

10 Ushakova, O.S. (2014). Razvitie rechi doshkolnikov: igry, uprazhneniia, konspekty zaniatii [Speech development of preschoolers: Games, exercises, lesson notes]. O.S. Ushakova (Ed.) (3d ed.) Moscow: TTS «Sfera» [in Russian].

11 Strunina, E. M., \& Ushakova, O.S. (1995). Semanticheskii aspekt v razvitii rechi starshikh doshkolnikov [Semantic aspect in the speech development of older preschoolers]. Razvitie rechi i rechevogo obshcheniia doshkolnikov [Development of speech and speech communication of preschool children]. O.S. Ushakova (Ed.). Moscow [in Russian].

12 Alekseeva, M.M., \& Yashina V.I. (2013) Teoriia i metodika razvitiia rechi detei: uchebnik dlia studentov uchrezhdenii vyssheho professionalnogo obrazovaniia [Theory and methodology of children's speech development: textbook for students of institutions of higher professional education]. Moscow: Akademiia [in Russian]. 